\title{
ROS-dependent $\mathrm{Bax} / \mathrm{Bcl} 2$ and caspase 3 pathway- mediated apoptosis induced by zineb in human keratinocyte cells
}

This article was published in the following Dove Press journal: OncoTargets and Therapy

\author{
Daoud Ali' \\ Abhilasha Tripathi ${ }^{2}$ \\ Hussain Al Ali ${ }^{3}$ \\ Yadvendra Shahi ${ }^{2}$ \\ Kamlesh K Mishra ${ }^{2}$ \\ Saud Alarifi' \\ Abdullah A Alkahtane' \\ Salem Manohardas' \\ 'Department of Zoology, Science \\ College, King Saud University, Riyadh, \\ Saudi Arabia; ${ }^{2}$ CytoGene Research \\ and Development, Lucknow, India; \\ ${ }^{3}$ Centre of Excellence for Genomics, \\ King Abdulaziz City for Science and \\ Technology, Riyadh, Saudi Arabia
}

Correspondence: Kamlesh K Mishra CytoGene Research and Development, Chauraha, Indira Nagar, Lucknow, Uttar Pradesh 226016, India

Tel +9l 9695988 I80

Email kmishrak5@gmail.com

\begin{abstract}
There are a large number of agricultural workers who are exposed to pesticides through skin and inhalation. The best approach to identify altered molecular pathways during dermal exposure to pesticides is relevant to risk-associated concern about skin safety. In this study, we investigated the cytotoxic effect of zineb, a fungicide, in human keratinocyte (HaCaT) cells. HaCaT cells were treated with zineb $(1-40 \mu \mathrm{g} / \mathrm{mL})$ for 24 hours. Cellular and molecular mechanisms of cell toxicity were investigated through MTT and neutral red-uptake assays. Zineb reduced viability of $\mathrm{HaCaT}$ cells and induced apoptosis in a concentration-dependent manner. Zineb increased levels of Bax and caspase 3 and inhibited the level of Bcl2, which subsequently induced apoptosis via the $\mathrm{Bax} / \mathrm{Bcl} 2$ and caspase pathway. Therefore, zineb could have induced apoptosis through the mitochondrial pathway in $\mathrm{HaCaT}$ cells. Our study suggests that zineb is cytotoxic to HaCaT cells via the induction of apoptosis and oxidative stress in vitro.
\end{abstract}

Keywords: zineb, HaCaT cells, apoptosis, MTT assay, DNA damage

\section{Introduction}

Pesticides, including insecticides, fungicides, and herbicides, are chemicals that protect crops from destruction caused by various harmful pests. Application of pesticides has been constantly increasing over the past few decades, despite their deleterious effects on human health owing to the persistent residual presence of such chemicals and their derivatives in consumable crops, which show bioaccumulation and biomagnification. Chronic exposure to pesticides can disturb the function of various organs in the body, including the integumentary, immune, nervous, cardiovascular, respiratory, and other systems. ${ }^{1,2}$ Mostly, pesticides are absorbed through the skin during mixing, loading, and processing. However, the skin is the most prospective body surface to come into contact with pesticides that can cause toxic effects. Zineb is a class of fungicide (bisdithiocarbamate), and is used in paints on leather, linen, and wood. It controls many fungal diseases in crops through the spraying of $2.5 \mathrm{~kg} / 1,000 \mathrm{~L}$ water/ha in fields, and has been found at $200 \mathrm{mg} / \mathrm{m}^{3}$ in the environment. ${ }^{3,4}$ It has been reported that zineb causes genotoxicity and cytotoxicity in various in vitro and in vivo models. ${ }^{5,6}$ Cecconi et $\mathrm{al}^{7}$ reported that zineb is toxic to insects and a metabolic poison for mammals.

Living skin cells can react to zineb in different ways, such as redness, pain, heat, and swelling, ie, inflammation. ${ }^{4}$ The degree of inflammation is a direct result of the concentration-dependent response to zineb. Excess inflammation can cause cell death, and then the manifestation will be much more severe. Zineb-induced cell death 
occurs when ROS are generated more quickly than they are scavenged by antioxidant defense mechanisms. ${ }^{8}$ Increased ROS levels in a cellular system can lead to damage to cellular DNA, proteins, lipids, and cellular and molecular changes that can result in cell toxicity and cell death. ${ }^{9,10}$ It is reported for the first time in this study that HaCaT cells exposed to zineb show significantly enhanced reactive oxygen species (ROS) levels and consequent increased DNA-strand breaks and decrease in cell viability in human keratinocytes. The current study was designed to assess the cytotoxicity of zineb, as well as to investigate the mechanism of zineb-induced cell death (apoptosis and necrosis) in $\mathrm{HaCaT}$ cells.

\section{Materials and methods \\ Chemicals and consumables}

Zineb (ethylene bisdithiocarbamate) was purchased from Sabero Organics (Mumbai, India). FBS, DMEM F12, antibiotics, trypsin, antimycotic solution, MTT, DCFH-DA, neutral red (NR) dye, acridine orange (AO), ethidium bromide (EtBr), PBS, propidium iodide, trypsin-EDTA solution, and cell-lysis solution were procured from Sigma-Aldrich (St Louis, MO, USA). Oligonucleotides were purchased from Integrated DNA Technologies (Coralville, IA, USA). A cDNA reverse-transcription kit, SYBR green, protein standard and Trizol reagent were bought from Thermo Fisher Scientific (Waltham, MA, USA).

\section{Cell culture}

$\mathrm{HaCaT}$ cells (human keratinocytes) was purchased from American Type Culture Collection (PCS-200-011; Rockville, MD, USA). These were cultured in DMEM with 10\% FBS in $1 \%-2 \%$ antibiotic-antimycotic solution. Cultures were grown with $95 \%$ humidity and $5 \% \mathrm{CO}_{2}$. Cells were viewed with phase-contrast microscopy (Nikon Eclipse TE2000).

\section{MTT assay}

The percentage cell viability of $\mathrm{HaCaT}$ cells was determined by MTT assay. ${ }^{11} \mathrm{HaCaT}$ cells were grown in 96-well plates to $80 \%$ confluence for the cytotoxicity assay, and exposed to different concentrations of zineb $(0-40 \mu \mathrm{g} / \mathrm{mL})$ for 24 hours, after which $0.5 \mathrm{mg} / \mathrm{mL}$ MTT was added and cells incubated for $4 \mathrm{~h}$. The MTT product (formazan crystal) concentration was determined at $550 \mathrm{~nm}$ using a microplate reader (Multiskan Ascent; MTX Lab Systems, Bradenton, FL, USA).

\section{Neutral red-uptake assay}

The NR-uptake (NRU) assay is a dye-inclusion assay. After treatment, plates were incubated for 4 hours with a supplemented medium containing $40 \mu \mathrm{g} / \mathrm{mL}$ NR. Cells were subsequently washed twice with DPBS and the dye extracted with $200 \mu \mathrm{L}$ destaining solution (ethanol, deionized water, and glacial acetic acid, 50:49:1 v:v:v). Absorbance was read at $540 \mathrm{~nm}$ using the microplate reader. Cell viability in terms of percentage of control was expressed in the same manner as for the MTT assay. All data are presented as mean $\pm \mathrm{SE}$ from three independent experiments.

\section{ROS measurement}

Generation of intracellular ROS was measured using DCFH-DA dye. HaCaT cells were cultured in 96-well plates and grown to $80 \%$ confluence. HaCaT cells were treated with various doses of zineb for 24 hours in the presence of $100 \mathrm{mM}$ $\mathrm{H}_{2}$-DCFH-DA. Finally, cells were washed with PBS and relative fluorescence intensity determined by spectrofluorometry at $480 \mathrm{~nm}$ excitation and $530 \mathrm{~nm}$ emission.

For qualitative analysis of intracellular ROS generation in $\mathrm{HaCaT}$ cells $\left(2 \times 10^{4}\right)$ after exposure to zineb, treated cells were incubated with $\mathrm{H}_{2}$-DCFH-DA in six-well plates in a $\mathrm{CO}_{2}(5 \%)$ incubator at $37^{\circ} \mathrm{C}$ for 30 minutes, then washed with normal PBS and fixed with paraformaldehyde (4\%). Fluorescence of HaCaT cells was observed by upright fluorescence microscopy (Nikon Eclipse 80i).

\section{Lipid peroxidation}

Lipid peroxidation was determined by evaluation of malondialdehyde (MDA) in accordance with Ohkawa et al. ${ }^{12} \mathrm{HaCaT}$ cells was cultured in six-well plates at $2 \times 10^{4}$ cells/well and exposed to different concentrations of zineb, HaCaT cell was scraped and cell lysate prepared in lysis buffer. Cell lysates $(100 \mu \mathrm{L})$ were mixed with $8.1 \%$ sodium dodecyl sulfate $(200 \mu \mathrm{L}), 20 \%$ acetic acid $(1.5 \mathrm{~mL})$ adjusted to $\mathrm{pH}$ 3.5 , and $1.5 \mathrm{~mL} 0.8 \%$ thiobarbituric acid. The solution was increased $4 \mathrm{~mL}$ by adding Milli-Q water and warmed to $95^{\circ} \mathrm{C}$ for 120 minutes. The solution was mixed with $n$-butanol and pyridine (15:1 v:v) and shaken at room temperature. The mixture was centrifuged at $3100 \times g$ for 15 minutes, supernatants collected, and optical density determined at $546 \mathrm{~nm}$. The quantity of MDA was measured according to a standard curve.

\section{Glutathione}

Glutathione was estimated by the method of Saldak and Lindsay. ${ }^{13}$ In brief, after exposure to zineb $(0-40 \mu \mathrm{g} / \mathrm{mL})$, treated cells were scraped and separated by centrifugation at $1,500 \mathrm{rpm}$ for 2 minutes at $4^{\circ} \mathrm{C}$ and lysed in lysis buffer. The cell extract $(100 \mu \mathrm{L})$ was mixed into reaction mixture $(500 \mu \mathrm{L}), 0.4 \mathrm{M}$ Tris buffer $(1,000 \mu \mathrm{L})$ and $0.01 \mathrm{M}$ 5,5-dithiobis-(2-nitrobenzoic acid) $(100 \mu \mathrm{L})$. The mixed cell lysate was put for 25 minutes at $37^{\circ} \mathrm{C}$ and after incubation it was 
read at $412 \mathrm{~nm}$ against blank. The amount of glutathione was expressed as $\mathrm{nM} / \mathrm{mg}$ protein.

\section{Superoxide dismutase (SOD)}

SOD activity was determined in accordance with Kono ${ }^{14}$ using nitroblue tetrazolium in the presence of riboflavin. After zineb $(0-40 \mu \mathrm{g} / \mathrm{mL})$ exposure, the cell was scraped and centrifuged at $1,500 \mathrm{rpm}$ for 2 minute at $4^{\circ} \mathrm{C}$ and lysed in lysis buffer. The cell extract $(100 \mu \mathrm{L})$ was mixed with $50 \mathrm{mM}$ sodium carbonate buffer $(1.9 \mathrm{~mL}), 1.6 \mathrm{mM}$ nitroblue tetrazolium $(30 \mu \mathrm{L})$, Triton $\mathrm{X}-100(6 \mu \mathrm{L})$ and $100 \mathrm{mM}$ hydroxylamine- $\mathrm{HCl}(20 \mu \mathrm{L})$. The reaction mixture was mixed very well and absorbance was read at $560 \mathrm{~nm}$ for 5 minutes against blanks (reaction mixtures and cell extract).

\section{Catalase}

Catalase activity was measured using the method described by Aebi. ${ }^{15}$ Briefly, after zineb $(0-40 \mu \mathrm{g} / \mathrm{mL})$ exposure, the cell was scraped and centrifuged at 1,500 rpm for 2 minute at $4^{\circ} \mathrm{C}$ and lysed in lysis buffer. The cell extract $(100 \mu \mathrm{L})$ was mixed with $\mathrm{H}_{2} \mathrm{O}_{2}$ phosphate buffer $(800 \mu \mathrm{L})$ and distilled water $(100 \mu \mathrm{L})$ and absorbance was read at $240 \mathrm{~nm}$ for 4 minutes against blank $\left(\mathrm{H}_{2} \mathrm{O}_{2} \mathrm{PBS}\right)$.

\section{Morphological changes in cells by EtBr-AO staining}

Qualitative analysis of normal, apoptotic, and necrotic cells was performed using EtBr/AO morphology assay. Subsequently, cells were exposed to zineb in a concentrationdependent manner. Cells were incubated with a cocktail of EtBr-AO (1 mM). After 30 minutes incubation, cells were washed three times with PBS. Apoptosis/necrosis was observed by fluorescence images in an upright microscope (Nikon Eclipse).

\section{Comet assay}

Comet assay was performed following the method of Ali et al. ${ }^{16}$ Cells were cultured in six-well plates. After 24 hours' incubation, cells were treated with and without zineb. The first layer ( $1 \%$ normal agarose) on slide was prepared and dried for $20 \mathrm{~min}$ and then 1\% low-melting-point agarose $(80 \mu \mathrm{L})$ was added to the cell suspension $(20 \mu \mathrm{L})$, covered with cover slip, and kept at $4^{\circ} \mathrm{C}$ for hardening. A third layer was prepared by $0.5 \%$ low-melting-point agarose $(80 \mu \mathrm{L})$, kept at $4{ }^{\circ} \mathrm{C}$ for hardening, and the coverslip removed. All slides were put in lysis solution overnight at $4^{\circ} \mathrm{C}$. Further, run electrophoresis at $16 \mathrm{~V}$ for $30 \mathrm{~min}$. Slides were neutralized with buffer for 5 minutes and stained with EtBr. Percentage tail DNA and olive tail moment (OTM) were applied to determine DNA damage in cells. We have taken total 50 cell images from each concentration (25 cell images from each replicate slide) for analysis of each experiment (Komet 5 image-analysis software).

\section{Western blot analysis}

$\mathrm{HaCaT}$ cells $\left(1.5 \times 10^{5}\right)$ were plated in six-well plates and incubated for 24 hours at room temperature. Cells were exposed to zineb for 24 hours. Protein was extracted with a cocktail of protein-lysis buffer and protease inhibitor $(15 \mu \mathrm{L} / \mathrm{mL})$. The concentration of protein was determined by the Bradford method. ${ }^{17}$ Protein in each treated sample was separated on SDS-PAGE (10\%), transferred onto polyvinylidene fluoride membranes, and aspecific sites blocked with 5\% nonfat dry milk for 1 hour. The primary human monoclonal antibodies $\beta$-actin, $\mathrm{Bax}, \mathrm{Bcl} 2$, and caspase $3(1: 1,500)$ were diluted as per the manufacturer's protocol, and put on the membrane for $24 \mathrm{~h}$ at $4^{\circ} \mathrm{C}$. After incubation, the membrane was washed three times with TBST (10 $\mathrm{mM}$ Tris- $\mathrm{HCl}, 150 \mathrm{mM} \mathrm{NaCl}$, and $0.05 \%$ Tween 20 ), secondary antibodies (HRP-conjugated) were mixed $(1: 2,000)$ and put on the membranes for 2 hours. After being washed three times with PBS, bands were visualized using an Immobilon chemiluminescent HRP substrate (Millipore).

\section{RNA extraction and quantitative RT-PCR}

With TRI reagent (Sigma-Aldrich), total RNA was extracted from $\mathrm{HaCaT}$ cells according to the manufacturer's instructions. Quantification of total RNA was determined at $260 \mathrm{~nm}$ by nanodrop spectrophotometry (ND-1000; Thermo Fisher Scientific). cDNA was synthesized by high-capacity reverse-transcription (RT) kit (RevertAid first-strand cDNAsynthesis kit; Thermo Fisher Scientific). For detection of caspase $3, \mathrm{Bax}, \mathrm{Bcl} 2$, and $\beta$-actin, mRNA polymerase chain reaction (PCR) primers were designed (Table 1 ).

\section{Statistical analysis}

Statistical differences were determined by one-way analysis of variance. Data are expressed as mean \pm SE for three independent experiments.

\section{Results Effect of zineb on cell viability}

Figure 1 shows percentage cell viability of $\mathrm{HaCaT}$ cells through MTT and NRU tests. Zineb significantly reduced cell viability above $10 \mu \mathrm{g} / \mathrm{mL}$ concentration (Figure 1 ). The highest toxicity of zineb was observed at $40 \mu \mathrm{g} / \mathrm{mL}$, and cell viability dropped by up to $70.5 \%$ compared to controls. For NRU assays, similar results were observed. Cell viability was 
Table I List of primer sequences

\begin{tabular}{ll}
\hline Genes & Primer sequence \\
\hline$\beta$-Actin & F-CCAACCGCGAGAAGATGA \\
Caspase 3 & R-CCAGAGGCGTACAGGGATAG \\
& F-AGGACTCTAGACGGCATCCA \\
Bax & R-CAGTGAGACTTGGTGCAGTGA \\
& F-TTCATCCAGGATCGAGCAGG \\
Bcl2 & R-TGAGACACTCGCTCAGCTTC \\
& F-TGGACAACCATGACCTTGGACAATCA \\
& R-TCCATCCTCCACCAGTGTTCCCATC \\
\hline
\end{tabular}

Abbreviations: $F$, forward; $R$, reverse.

reduced by $62 \%$ at the same concentration of zineb $(P<0.01)$. Zineb $(20 \mu \mathrm{g} / \mathrm{mL})$ caused more than $50 \%$ cell death in MTT and NRU assays. As such, we found the $\mathrm{EC}_{50}$ 24-hour value of zineb $25 \mu \mathrm{g} / \mathrm{mL}$ for $\mathrm{HaCaT}$ cells.

\section{ROS generation and oxidative stress}

To assess oxidative stress in $\mathrm{HaCaT}$ cells due to zineb exposure, we evaluated the quantitative and qualitative generation of fluorescent DCF (the result of DCFH oxidation by different peroxides). Zineb-exposed $\mathrm{HaCaT}$ cells showed significant enhancement in production of ROS in terms of DCF-florescence intensity. Fluorescence-intensity increased to $445 \%$ and $436 \%$ in the 20 and $40 \mu \mathrm{g} / \mathrm{mL}$ zinebtreated groups for 24 hours' exposure compared to controls (Figure 2).

Zineb induced lipid peroxidation in $\mathrm{HaCaT}$ cells. After 24 hours incubation with different concentrations of zineb, MDA levels were increased compared to controls (Figure 3A). Results showed that zineb-induced oxidative stress was further evidenced by depletion of glutathione (Figure 3B) and enhanced SOD and catalase levels at $10 \mu \mathrm{g} / \mathrm{mL}$, but, however, SOD and catalase levels declined slightly at $40 \mathrm{mg} / \mathrm{mL}$ in comparison to $10 \mu \mathrm{g} / \mathrm{mL}$ (Figure 3C and D).

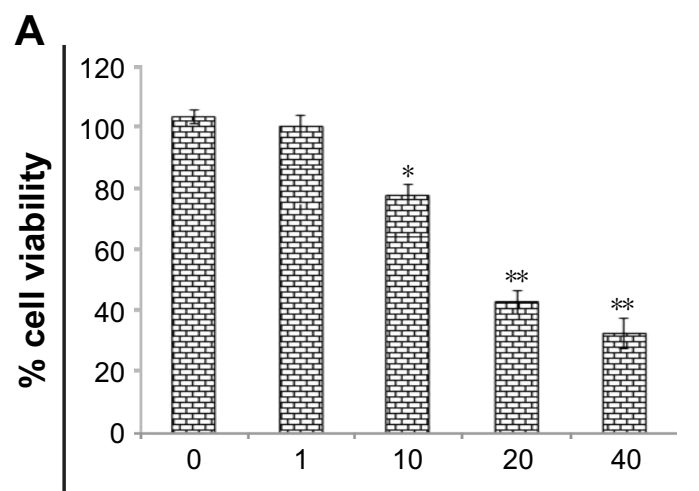

\section{$\mathrm{AO}-\mathrm{EtBr}$ staining}

The effect of zineb showed enhanced apoptosis, which was measured by $\mathrm{AO} / \mathrm{EtBr}$ morphological assays in $\mathrm{HaCaT}$ cells (Figure 4). Live cells exhibited normal nuclear chromatin with green fluorescence, but apoptotic cells had fragmented DNA (intense orange). Zineb treatment resulted in a significant number of apoptotic cells compared to controls (Figure 4A-C).

\section{DNA damage}

Fragmentation of DNA was measured using the alkaline comet assay, a sensitive tool for measuring DNA-strand breakage in individual cells. ${ }^{18}$ DNA damage (percentage tail DNA and OTM) reached about 5.6-fold and 3-fold control values after 24 hours zineb exposure at concentrations of 40 and $20 \mu \mathrm{g} / \mathrm{mL}$, respectively (Figure 5). Indeed, zineb induced DNA damage in a concentration-dependent manner.

\section{Western blot analysis}

Western blot data showed that there was a significant increase in Bax:Bcl2 ratio expression in zineb over control groups. Further significant increase in expression levels of caspase 3 was found in zineb-treated cells over controls (Figure 6).

\section{mRNA expression in $\mathrm{HaCaT}$ cells analyzed by RT-PCR}

Expressions of caspase 3, Bax, and Bcl2 were analyzed by quantitative RT-PCR with and without (control) zineb treatment. Results showed significant $(P<0.01)$ upregulation of $\mathrm{Bax}$ and downregulation of $\mathrm{Bcl} 2$ in treated cells over controls, as well as increased expression of caspase 3 in treated $\mathrm{HaCaT}$ cells (Figure 7).

B

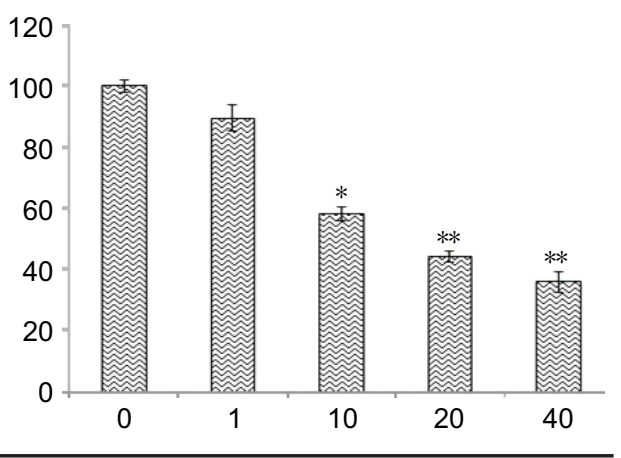

\section{Concentration $(\mu \mathrm{g} / \mathrm{mL})$}

Figure I Cytotoxicity of zineb in $\mathrm{HaCaT}$ cells for 24 hours.

Notes: (A) MTT assay; (B) NRU assay. Each value represents the mean \pm SE of three experiments. $* P<0.05$ and $* * P<0.0$ I vs control.

Abbreviation: NRU, neutral red uptake. 
A

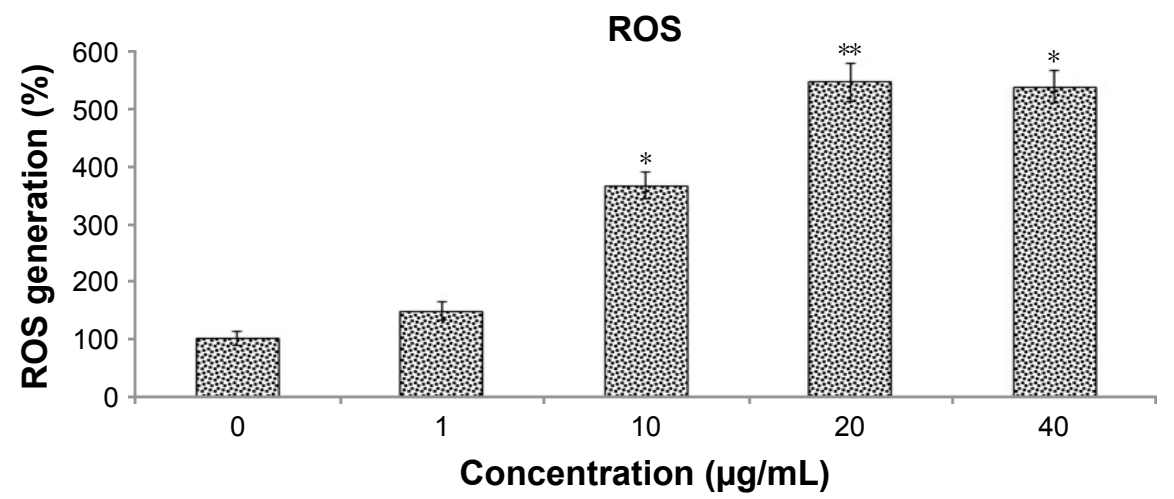

B

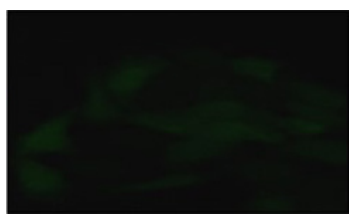

Control

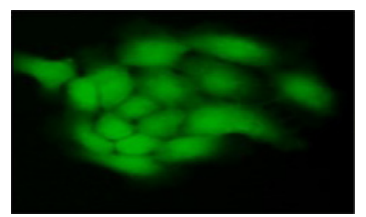

10

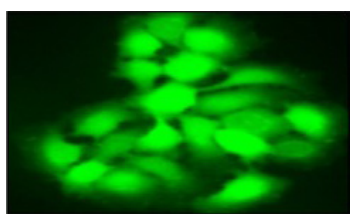

20

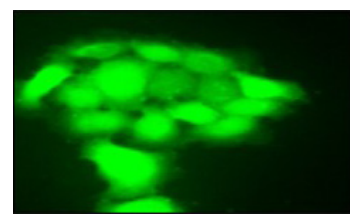

40

Concentration $(\mu \mathrm{g} / \mathrm{mL})$

Figure 2 Zineb-induced ROS in $\mathrm{HaCaT}$ cells.

Notes: (A) ROS generation (\%) in $\mathrm{HaCaT}$ cells; (B) fluorescence intensity of intracellular ROS generation in HaCaT cells after zineb exposure for 24 hours. Images were taken with phase-contrast fluorescence microscopy (Nikon 80i; Melville, NY, USA). Magnification: $40 \times$. Each value represents the mean \pm SE of three experiments. $* P<0.05$ and $* * P<0.01$ vs control.

Abbreviation: ROS, reactive oxygen species.

\section{Discussion}

The concern of toxicity in reference to pesticides has been a key dilemma for human health for the past few decades. Pesticides were developed to control pests for more and safer production, but several pesticides present prospective risks to human health and the environment. Zineb is one of the most widely used commercial fungicides worldwide. Concerns related to fungicide use and human health have been raised, due to the injurious effect on individuals exposed to them. Specifically, exposure to fungicides has revealed a connection
A

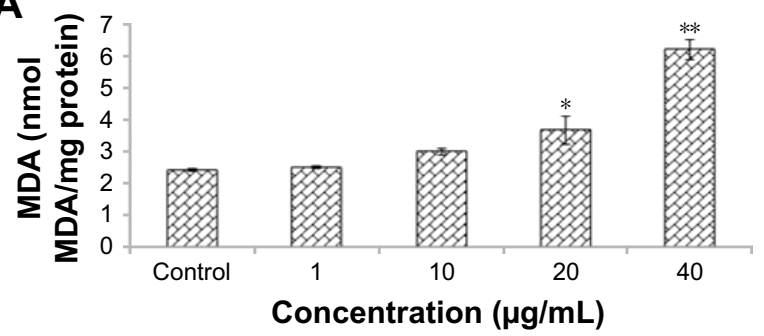

C

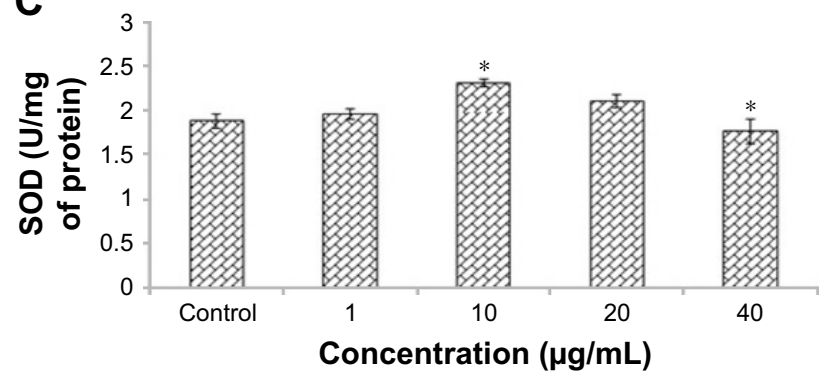

B
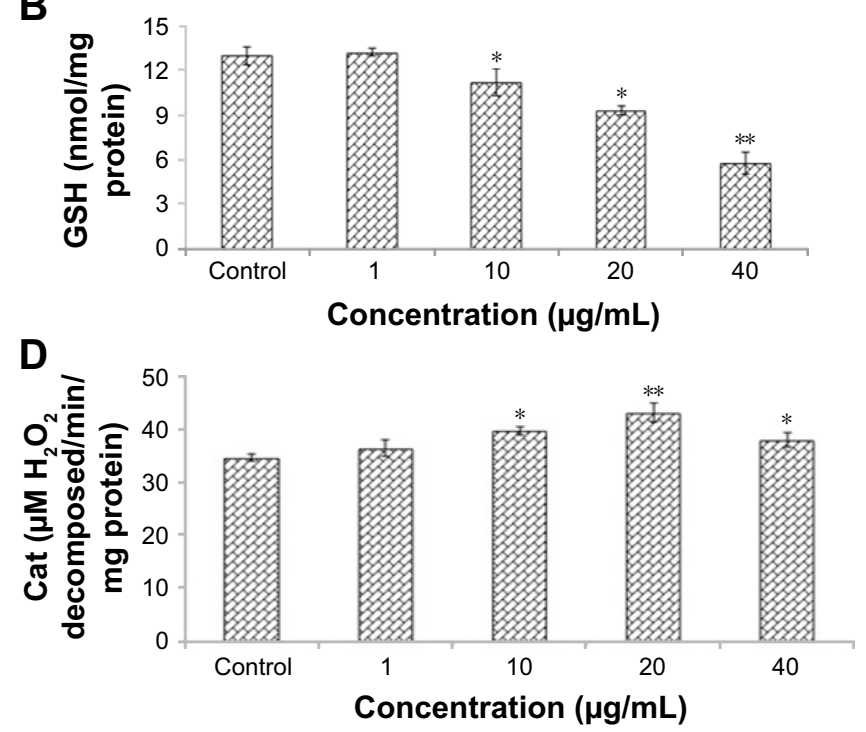

Figure 3 Levels of (A) LPO, (B) GSH, (C) SOD, and (D) Cat activity in HaCaT cells after exposure to zineb for 24 hours.

Notes: Each value represents the mean \pm SE of three experiments. $* P<0.05$ and $* * P<0.01$ vs control.

Abbreviations: Cat, catalase; GSH, glutathione; LPO, lipid peroxidation; MDA, malondialdehyde; SOD, superoxide dismutase. 

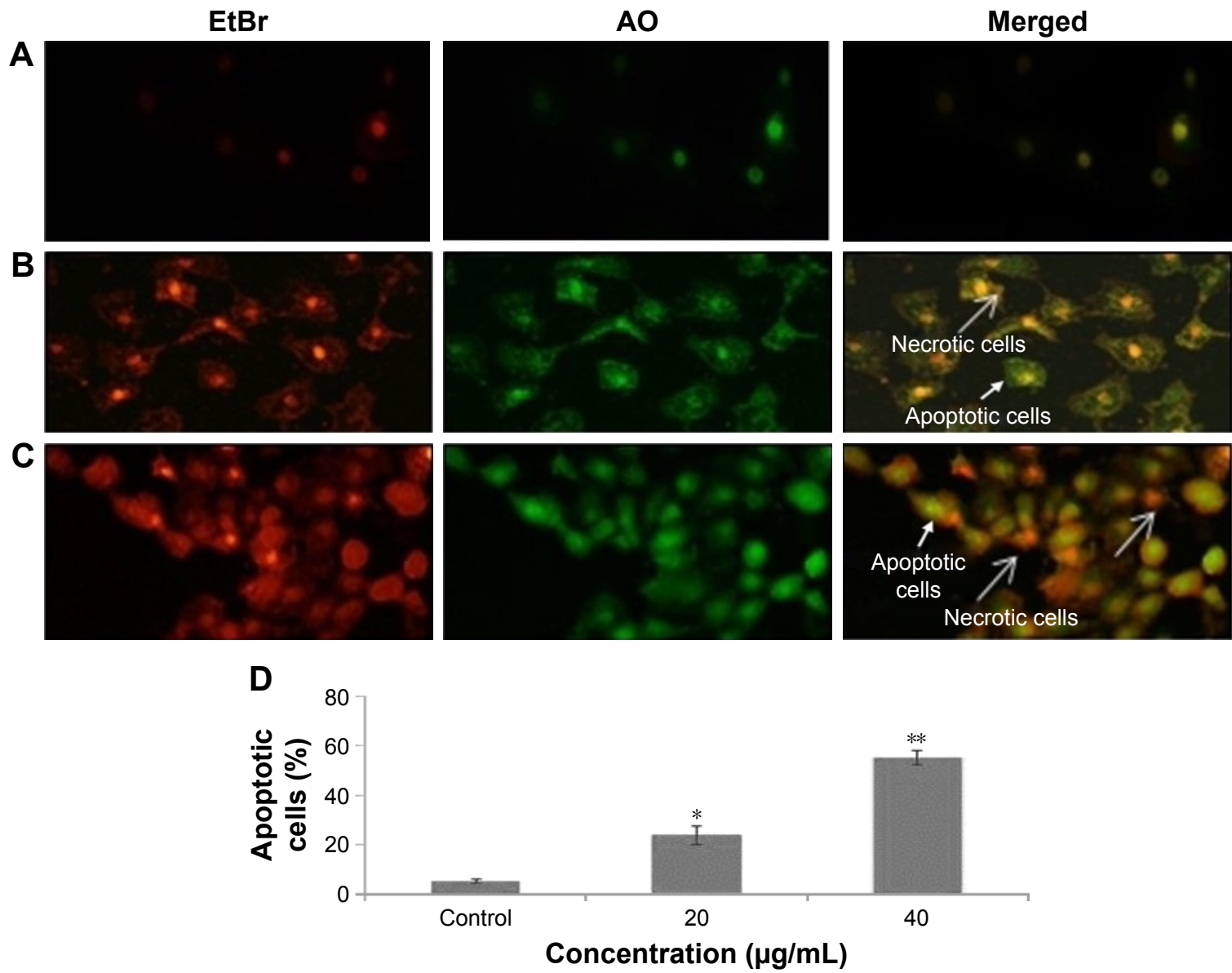

Figure $4 \mathrm{EtBr}-\mathrm{AO}$ double staining was used to identify live cells (green), apoptotic cells (orange), and necrotic cells (red).

Notes: (A) Control cells; (B) $20 \mu \mathrm{g} / \mathrm{mL}$ zineb-exposed cells; (C) $40 \mu \mathrm{g} / \mathrm{mL}$ zineb-exposed cells; (D) graphic representation of apoptotic cells. Note that EtBr entered damaged cells only and bound with condensed nuclear material. Mean $\pm \mathrm{SE}$ of three experiments are shown. $* \mathrm{P}<0.05$ and $* * P<0.0 \mathrm{l}$ compared to control.

Abbreviations: $\mathrm{AO}$, acridine orange; $\mathrm{EtBr}$, ethidium bromide.
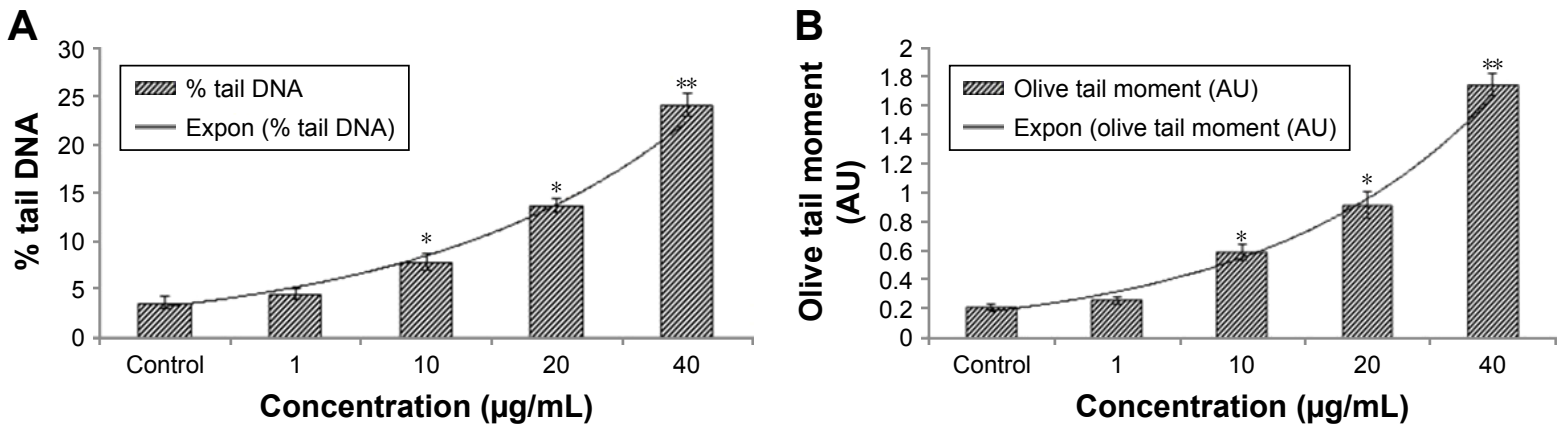

C

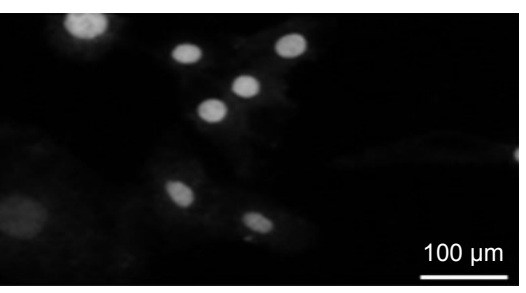

D

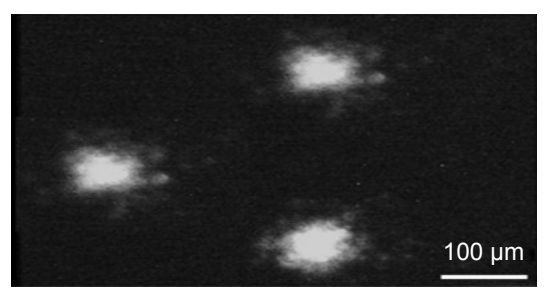

Figure 5 DNA-strand breakage in $\mathrm{HaCaT}$ cells due to zineb.

Notes: (A) Tail DNA (\%), (B) olive tail moment, and (C) control cells, and (D) at $40 \mu \mathrm{g} / \mathrm{mL}$ for 24 hours. Each value represents the mean \pm SE of three experiments. $* P<0.05$ and $* * P<0.0$ I vs control.

Abbreviation: Expon, exponential. 
A
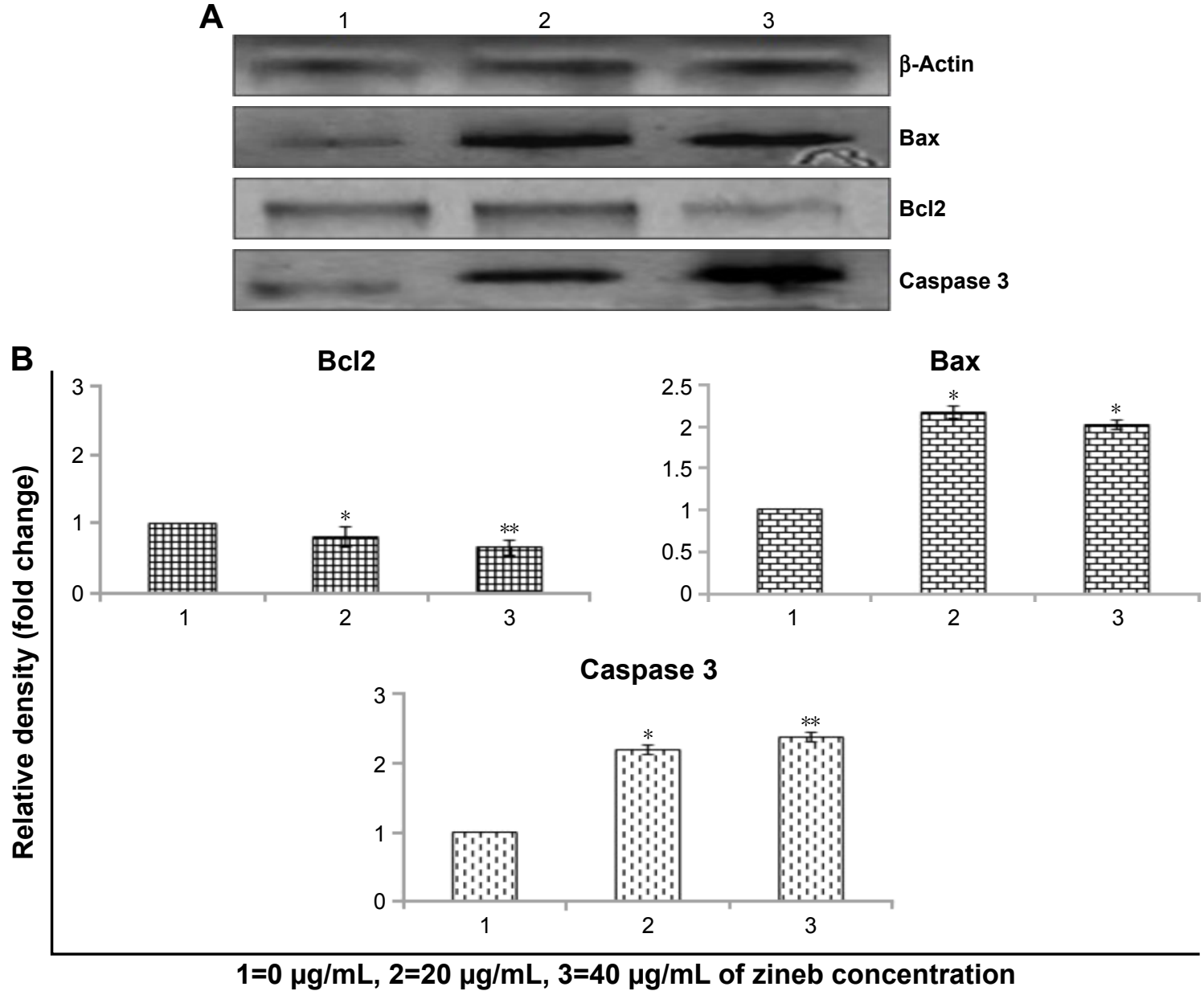

Figure 6 Western blot analysis of protein involved in apoptosis due to zineb for 24 hours' exposure.

Notes: (A) Bax, Bcl2, and caspase 3. $\beta$-Actin was used as internal control to normalize the results. (B) Relative quantification of protein-expression levels. Results expressed as mean \pm SE of triplicate experiments. $* P<0.05$ and $* * P<0.0$ I vs control.

with progress of skin diseases. ${ }^{19,20}$ Meanwhile, as skin receives maximum exposure to zineb and other fungicides, it is important to identify their toxicity. Some researchers have recognized the dermal molecular toxicity mechanism of zineb and other fungicides that are widely used. We studied the mechanisms of geno/cytotoxic molecules of zineb using the illustrative human keratinocyte $\mathrm{HaCaT}$ cell line as an in vitro skin model. It has been found that numerous fungicides which are applied to inhibit soybean rust can also suppress the cell growth and disrupt the ovarian cell cycle, and zineb exhibits a more significant toxic response. ${ }^{21}$ This shows the cytotoxicity of zineb on $\mathrm{HaCaT}$ cells. Cell toxicity was increased in a dose dependent manner after 24-hour exposure, and this indicates that zineb can activate cell death in keratinocytes. There are diverse mechanisms of cell death, including necrosis, apoptosis, mitotic catastrophe, and pyroptosis. ${ }^{22}$ Several studies have established that pesticides can induce cell apoptosis, resulting in dysregulation of associated functions. ${ }^{23-25}$ Apoptosis is programmed cell death that serves as a mechanism to maintain homeostasis in normal cells, and initiation of apoptosis may be a principal pathological event that causes cell alteration and diseases. ${ }^{26} \mathrm{EtBr}-\mathrm{AO}$ morphological assays showed that late apoptosis in the form of red fluorescence occur in $\mathrm{HaCaT}$ cells rather than necrosis. We also demonstrated that zineb induced apoptosis was a mechanism of toxicity. Molecular markers of cell death, such as Bax:Bcl2 ratio and caspases, showed an increase in late apoptosis compared with controls upon zineb treatment, and exposed cells showed significant DNA damage (percentage tail and OTM), a characteristic of apoptosis. In addition, gene expression and proteins involved in apoptotic pathways were upregulated due to zineb treatment. Bax/Bcl2 and caspase 3 induce intrinsic/extrinsic pathways of apoptosis, ${ }^{27}$ and caspase 3 is a final executioner in extrinsic pathways. ${ }^{28}$

Figure 6 indicates that zineb induced $\mathrm{Bax} / \mathrm{Bcl} 2$ and caspase 3 protein expression. Figure 7 indicates that zineb 


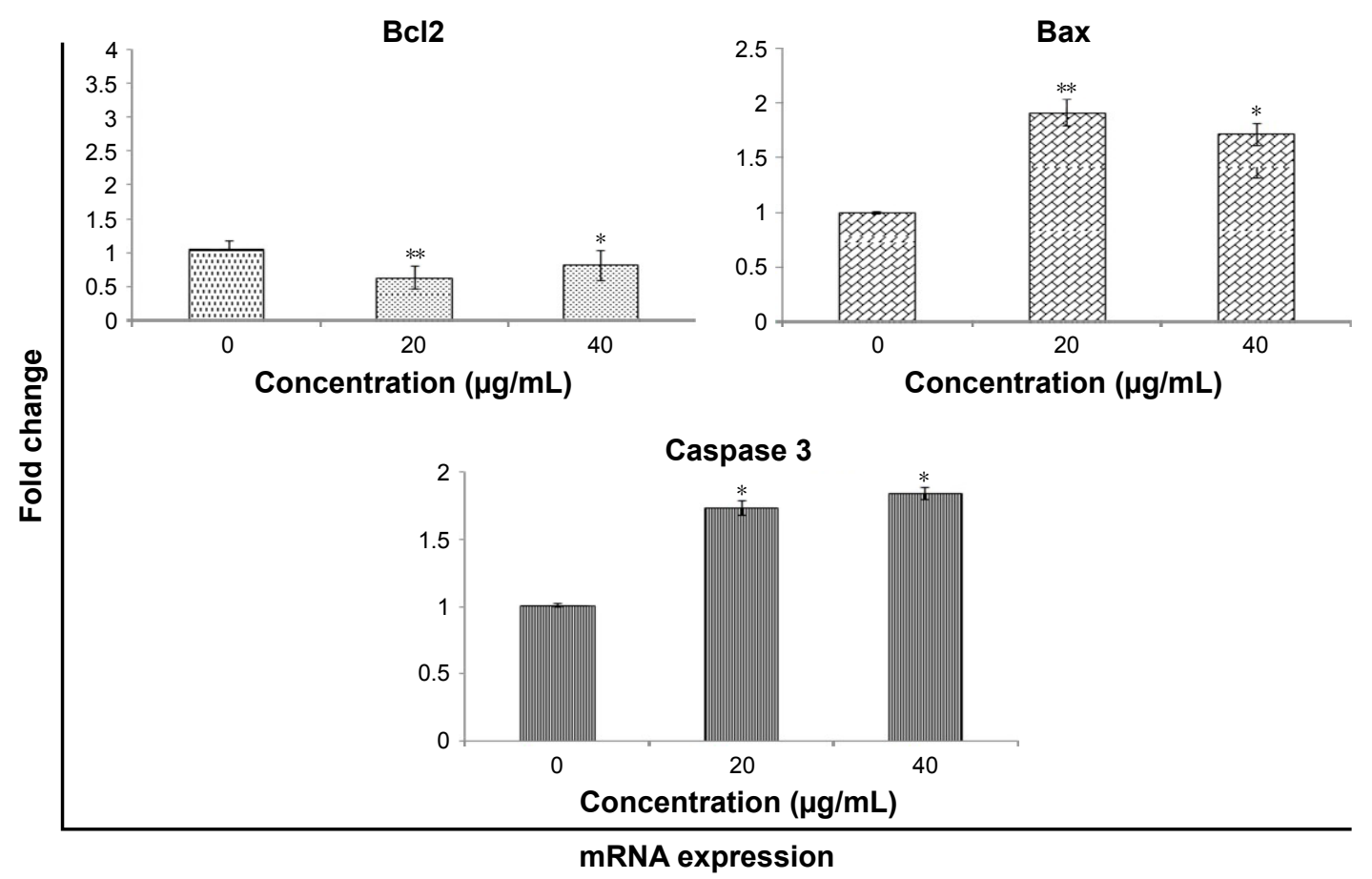

Figure 7 mRNA expression of $\mathrm{Bcl} 2$, Bax, and caspase 3 in $\mathrm{HaCaT}$ cells treated and not treated with zineb. Notes: Results expressed as mean \pm SE of triplicate experiments. $* P<0.05$ and $* * P<0.01$ vs control.

upregulated $B A X$ and $C A S P 3$ and downregulated $B C L 2$ gene expression. These data imply that ROS mediate mitochondriadependent pathways involved in zineb-induced apoptosis. It is well acknowledged that the $\mathrm{Bax} / \mathrm{Bcl} 2$ is involved with levels of mitochondrial membrane potential. ${ }^{29,30} \mathrm{Zineb}$ induced the caspase 3 enzyme as a consequence of apoptosis in $\mathrm{HaCaT}$ cells. We found that zineb produced significant toxicity in $\mathrm{HaCaT}$ cells in a concentration-dependent manner in the range $0-40 \mu \mathrm{g} / \mathrm{mL}$. Zineb also increased the level of Bax, inhibited levels of $\mathrm{Bcl} 2$, and triggered caspase 3 activity, which subsequently evinced apoptosis via the $\mathrm{Bax} / \mathrm{Bcl} 2$ and caspase 3 pathway.

\section{Conclusion}

We established the apoptotic and cell-toxicity effects of zineb in human keratinocyte cells in vitro. Our findings show consumers and agricultural agencies the potential risks of zineb and zineb-containing products.

\section{Acknowledgment}

The authors extend their appreciation to the Deanship of Scientific Research at King Saud University for funding this work through Research Group RGP-1435-076.

\section{Disclosure}

The authors report no conflicts of interest in this work.

\section{References}

1. de Souza A, Medeiros AR, de Souza AC, et al. [Evaluation of the impact of exposure to pesticides on the health of the rural population: Vale do Taquari, state of Rio Grande do Sul (Brazil)]. Cien Saude Colet. 2011; 16:3519-3528. Portuguese.

2. Mostafalou S, Abdollahi M. Pesticides and human chronic diseases: evidences [sic], mechanisms, and perspectives. Toxicol Appl Pharmacol. 2013;268:157-177.

3. Indian Agricultural Research Institute. Technological Options for Enhanced Productivity and Profit. New Delhi: IARI; 2014.

4. ExToxNet. Cutaneous toxicity: toxic effects on skin. 1993. Available from: http://pmep.cce.cornell.edu/profiles/extoxnet/TIB/cutaneous-tox. html. Accessed November 6, 2017.

5. Elia MC, Arce G, Hurt SS, O’Neill PJ, Scribner HE. The genetic toxicology of ethylenethiourea: a case study concerning the evaluation of a chemical's genotoxic potential. Mutat Res. 1995;341:141-149.

6. Soloneski S, Reigosa MA, Larramendy ML. Effect of the dithiocarbamate pesticide zineb and its commercial formulation, the Azzurro - V: abnormalities induced in the spindle apparatus of transformed and nontransformed mammalian cell lines. Mutat Res. 2003;536:121-129.

7. Cecconi S, Paro R, Rossi G, Macchiarelli G. The effects of the endocrine disruptors dithiocarbamates on the mammalian ovary with particular regard to mancozeb. Curr Pharm Des. 2007;13:2989-3004.

8. Jia Z, Misra HP. Reactive oxygen species in in vitro pesticide-induced neuronal cell (SH-SY5Y) cytotoxicity: role of NFKB and caspase-3. Free Radic Biol Med. 2007;42:288-298.

9. Finkel T, Holbrook NJ. Oxidants, oxidative stress and the biology of aging. Nature. 2000;408:239-247.

10. Valko M, Leibfritz D, Moncol J, Cronin MT, Mazur M, Telser J. Free radicals and antioxidants in normal physiological functions and human disease. Int J Biochem Cell Biol. 2007;39:44-84.

11. Mosmann T. Rapid colorimetric assay for cellular growth and survival: application to proliferation and cytotoxicity assays. J Immunol Methods. 1983;65:55-63.

12. Ohkawa H, Ohishi N, Yagi K. Assay for lipid peroxides in animal tissues by thiobarbituric acid reaction. Anal Biochem. 1979;95:351-358. 
13. Saldak J, Lindsay RH. Estimation of total, protein-bound, and nonprotein sulfhydryl groups in tissue with Ellman's reagent. Anal Biochem. 1968;25:192-205.

14. Kono Y. Generation of superoxide radical during autoxidation of hydroxylamine and an assay for superoxide dismutase. Arch Biochem Biophys. 1978;186:189-195.

15. Aebi H. Catalase. In: Bergmeyer HU, editor. Methods of Enzymatic Analysis. New York: Academic Press; 1974:673-684.

16. Ali D, Verma A, Mujtaba SF, Dwivedi A, Hans RK, Ray RS. UVB-induced apoptosis and DNA damaging potential of chrysene via reactive oxygen species in human keratinocytes. Toxicol Lett. 2011;204:199-207.

17. Bradford MM. A rapid sensitive method for the quantification of microgram quantities of protein utilizing the principle of protein-dye binding. Anal Biochem. 1976;72:248-254.

18. Kang C, Xu Q, Martin TD, et al. The DNA damage response induces inflammation and senescence by inhibiting autophagy of GATA4 Science. 2015;349:aaa5612.

19. Guo YL, Wang BJ, Lee CC, Wang JD. Prevalence of dermatoses and skin sensitization associated with the use of pesticides in fruit farmers of southern Taiwan. Occup Environ Med. 1996;53:427-431.

20. Spiewak R. Pesticides as a cause of occupational skin diseases in farmers. Ann Agric Environ Med. 2001;8:1-5.

21. Daniel SL, Hartman GL, Wagner ED, Plewa MJ. Mammalian cell cytotoxicity analysis of soybean rust fungicides. Bull Environ Contam Toxicol. 2007;78:474-478.

22. Kroemer G, Galluzzi L, Vandenabeele P, et al. Classification of cell death: recommendations of the Nomenclature Committee on Cell Death 2009. Cell Death Differ. 2009;16:3-11.
23. Ahmadi FA, Linseman DA, Grammatopoulos TN, et al. The pesticide rotenone induces caspase-3-mediated apoptosis in ventral mesencephalic dopaminergic neurons. J Neurochem. 2003;87:914-921.

24. Calviello G, Piccioni E, Boninsegna A, et al. DNA damage and apoptosis induction by the pesticide mancozeb in rat cells: involvement of the oxidative mechanism. Toxicol Appl Pharmacol. 2006;211:87-96.

25. Fukuyama T, Kosaka T, Tajima Y, Hayashi K, Shutoh Y, Harada T. Detection of thymocytes apoptosis in mice induced by organochlorine pesticides methoxychlor. Immunopharmacol Immunotoxicol. 2011;33: 193-200.

26. MacFarlane M, Williams AC. Apoptosis and disease: a life or death decision. EMBO Rep. 2004;5:674-678.

27. Zou H, Henzel WJ, Liu X, Lutschg A, Wang X. Apaf1, a human protein homologous to C. elegans CED-4, participates in cytochrome C-dependent activation of caspase-3. Cell. 1997;90:405-413.

28. Falschlehner C, Emmerich CH, Gerlach B, Walczak H. TRAIL signaling: decisions between life and death. Int J Biochem Cell Biol. 2007; 39:1462-1475.

29. Barlow BK, Lee DW, Cory-Slechta DA, Opanashuk LA. Modulation of antioxidant defense systems by the environmental pesticide maneb in dopaminergic cells. Neurotoxicology. 2005;26:63-75.

30. Drechsel DA, Patel M. Role of reactive oxygen species in the neurotoxicity of environmental agents implicated in Parkinson's disease. Free Radic Biol Med. 2008;44:1873-1886.
OncoTargets and Therapy

\section{Publish your work in this journal}

OncoTargets and Therapy is an international, peer-reviewed, open access journal focusing on the pathological basis of all cancers, potential targets for therapy and treatment protocols employed to improve the management of cancer patients. The journal also focuses on the impact of management programs and new therapeutic agents and protocols on

\section{Dovepress}

patient perspectives such as quality of life, adherence and satisfaction. The manuscript management system is completely online and includes a very quick and fair peer-review system, which is all easy to use. Visit http://www.dovepress.com/testimonials.php to read real quotes from published authors. 